\title{
Sports Competition Anxiety among Netball Players
}

\author{
${\text { Aejaz } \operatorname{Hassan}^{1} \text {, Javaid Ahmad Bhat }}^{2}$, Dr. P.V. Shelvam ${ }^{3}$
}

\section{ABSTRACT}

The present study was aimed to investigate the sports competition anxiety among netball players for this purpose the investigator collect data from 50 netball players divided in two groups (30 males and 20 females). Further these two groups were divided into two more groups' senior and junior players. Data was collected through Random sampling method by applying sports competition anxiety test developed by Marten 1977. For data analysis t-test was applied. Results revealed that there is no significant difference found between mean scores of sports competition anxiety among male and female netball players also insignificant difference were found among senior and junior players in respect to sports competition anxiety. Further findings show that male and senior players have high levels of sports competition anxiety than female and junior netball players.

Keywords: Sports Competition Anxiety, Gender, Senior and Junior.

In present days the emphasis in sport psychology has shifted away from study of sample arousal in favor of looking at the more complex phenomena of anxiety. Psychologists believed that some psychological factors like fear and anxiety have a vital role in competition and in competitive sports, every athlete experience fear before, during and after events (Lizuka, 2005). Anxiety is a specific unpleasurable quality, efferent or discharge phenomenon and perception of these (Frued 1949). Anxiety is a negative emotional state with feelings of nervousness, worry and apprehension associated with activation of the body (Weinberg \& Gould 1995) (cited from Jarvis 2006).

Anxiety can have a devastating effect on the performance of an athlete. No matter how talented or skilled a person is, he will never perform best if he loses his control on fear before every event. Sports anxiety is a kind of anxiety that drives a tendency to evaluate the competition situations as threatening, and in response to this situation, there is an anxious state. According to

\footnotetext{
${ }^{1}$ Ph.D Research Scholar Physical Education \& Sports Sciences Annamalai University, India

${ }^{2}$ Ph.D Research Scholar Physical Education \& Sports Sciences Annamalai University, India

${ }^{3}$ Professor Department of Physical Education \& Sports Sciences Annamalai University, India

*Responding Author

(C) 2016, A Hassan, J Bhat, P Shelvam; licensee IJIP. This is an Open Access Research distributed under the terms of the Creative Commons Attribution License (http://creativecommons.org/licenses/by/2.0), which permits unrestricted use, distribution, and reproduction in any Medium, provided the original work is properly cited.
} 


\section{Sports Competition Anxiety among Netball Players}

Vujanovic \& Tisma (2011) sports anxiety refers to the emotional state of fear, tension in a concrete sporting event. Martens et al., (1990) in their multidimensional theory of anxiety underlines the fact that anxiety includes somatic and cognitive components as well as self-confidence.

Continuously high levels of anxiety during sports have significant impact on performance results failure. Hann (2000) believe that high levels of anxiety during competition are harmful it worsening performance and even leading to dropout. Therefore, it's very important to know the level of anxiety among sports persons so important measures can be taken by coaches, sport psychologists and trainers to overcome the effect of anxiety among sports persons. Researchers conducted various studies to highlight the cases, consequences and affect of sports competition anxiety on sports persons, Inder (2015) undercover the sports competition anxiety among volleyball and soccer male players. Results show no significant difference between volleyball and soccer male players in their sports competition anxiety. Singh \& Pal (2015) also highlights anxiety level of Kho-Kho players at national level. Mitra \& Gayen (2014) assessed sports competition anxiety level among basketball, football and volleyball players. Results revealed no significant differences were found among the selected three ballgame players in respect to sports competition anxiety. Nayek \& Chatterjee (2014) found significant difference on pre competition anxiety between national level and state level women athletes. Results also show that national level women athletes had less level of pre-competition anxiety than the state level women athletes. Rastogia \& Katiyar (2014) revealed that there is significant difference between chess players and cricket players in respect to sports competition anxiety. Quadri (2013) conducted a study on self concept and anxiety among boys and girls school players. Results show that girl's players shows high anxiety level than boy's players. Ali et al., (2012) highlights that increasing personal standards (P.S.) and perceived coach pressure (PCP) results in decreases trait anxiety while as increasing concern over mistakes (COM) and perceived parental pressure (PPP) also increases trait anxiety. Hannon \& Fitzgerald (2006) examined the anxiety and performance in selected non-professional athletes. Results revealed that there was a significantly negative correlation between anxiety scores and performance on the irritability, depression \& anxiety questionnaire. Humara (1999) revealed that women have a higher level of cognitive anxiety. Simon \& Martens (1977) also found higher levels of that competitive state anxiety among amateur individual athletes than athletes in team sports.

\section{Problem}

- To assess the level of sports competition anxiety among netball players.

\section{Objectives}

1. To find the level of sports competition anxiety among male and female netball players.

2. To find the level of sports competition anxiety among senior and junior netball players. 


\section{Sports Competition Anxiety among Netball Players}

\section{Hypotheses}

1. There would be no significant difference found among male and female netball players in sports competition anxiety.

2. There would be no significant difference found among senior and junior netball players in sports competition anxiety.

\section{METHOD}

\section{Samples}

The present study consists of 50 samples (30 male and 20 female) netball players. In male group 15 was seniors and 15 junior players similarly in female group 10 was seniors and 10 junior players.

\section{Procedure}

The investigator collects the date through random sampling method by using sports competition anxiety test developed by Marten 1977. Proper rapport was established with the subject and over view of the study was given to them. Later sports competition anxiety test questionnaire was given to each subject and were asked to read the instructions given carefully. Thus after 10 minutes subjects hand over the questionnaire to investigator and were thanked by him therefore the data was collected in proper way.

\section{RESULTS}

The main purpose of the present study was to find the level of sports competition anxiety among netball players. For that data was collected from Annamalai University. The obtained data was statistically analyzed by applying, Mean, SD, SED and t- test. The obtained results of the present study are shown in tables given below.

Table-1 Showing mean, S.D, $S_{E} D$ and $t$ - value of male and female netball players

\begin{tabular}{|c|c|c|c|c|c|c|c|}
\hline Group & Scores & No & Mean & SD & S & df & t- value \\
\cline { 1 - 5 } Male & 872 & 30 & 29.06 & 30.75 & & & \\
\cline { 1 - 5 } Female & 562 & 20 & 28.1 & 29.93 & 8.73 & 48 & 0.10 \\
\hline
\end{tabular}

Table- 2 Showing mean, S.D, $S_{E} D$ and t-value of senior and junior netball players

\begin{tabular}{|c|c|c|c|c|c|c|c|}
\hline Group & Scores & No & Mean & SD & S $\mathbf{E}$ & df & t- value \\
\cline { 1 - 6 } Senior & 785 & 25 & 31.4 & 33.00 & & & \\
\cline { 1 - 4 } Junior & 649 & 25 & 25.96 & 27.62 & 8.60 & 48 & 0.63 \\
\hline
\end{tabular}

Table- 3 Showing mean, S.D, $S_{E} D$ and $t$ - value of male senior and junior netball players

\begin{tabular}{|c|c|c|c|c|c|c|c|}
\hline Group & Scores & No & Mean & SD & SE & df & t- value \\
\hline Senior & 486 & 15 & 32.4 & 34.39 & & & \\
\cline { 1 - 4 } Junior & 386 & 15 & 25.73 & 27.86 & 11.42 & 28 & 0.58 \\
\hline
\end{tabular}

(C) The International Journal of Indian Psychology, ISSN 2348-5396 (e) | ISSN: 2349-3429 (p) | 139 
Sports Competition Anxiety among Netball Players

Table- 4 Showing mean, S.D, $S_{E} D$ and $t$ - value of female senior and junior netball players

\begin{tabular}{|c|c|c|c|c|c|c|c|}
\hline Group & Scores & No & Mean & SD & S $_{\mathbf{E}} \mathbf{D}$ & df & t- value \\
\hline Senior & 299 & 10 & 29.9 & 32.62 & & & \multirow{2}{*}{0.26} \\
\hline Junior & 263 & 10 & 26.3 & 28.76 & 13.75 & 8 & 0.76 \\
\hline
\end{tabular}

\section{DISCUSSION}

The results of present study demonstrated that there is no significant difference found between mean scores of sports competition anxiety among male and female netball players also insignificant difference were found among senior and junior players in respect to sports competition anxiety.

The mean scores of sports competition anxiety of male players were found 29.6 which is less than the mean scores of female players (28.1) similarly S.D. scores of male players (30.75) was found more than the S.D. scores of female player (29.93). The $\mathrm{SE}_{\mathrm{D}}$ was found 8.73 and obtained $\mathrm{t}$-value is found 0.10 with $\mathrm{df} 48$ which is less than tabulation value at 0.05 level which means that our obtained t- value is insignificant at 0.05 level of significance. It indicates that there is a no significant difference found between the mean scores of male and female players in respect to sports competition anxiety. Therefore first hypothesis "there would be no significant difference found among male and female netball players in sports competition anxiety" is accepted. These findings are supported by the research done by Singh \& Singh (2015) they investigate anxiety level between boys and girls. Results were found insignificant at 0.05 levels.

The mean of anxiety scores of senior and junior players were found 31.4 and 25.95 with S.D. value of 33.00 and 27.62 respectively the $\mathrm{SE}_{\mathrm{D}}$ value was found 8.60 and the obtained t-value 0.63 with $\mathrm{df} 48$ is found insignificant at 0.05 level of significance thus our second hypothesis "there would be no significant difference found among senior and junior netball players in sports competition anxiety" is accepted.

In the present study we also found that the mean, S.D, $S_{E} D$ and t-value scores for sports competition anxiety of male senior and junior players was found [(M=32.4,S.D=34.39)] $[(M=25.73, S . D=27.86)], S_{E} D=11.42$ and $t-v a l u e=0.58$ with $d f 28$ is found insignificant at 0.05 level of significance.

The mean, S.D, $S_{E} D$ and t-value scores for sports competition anxiety of female senior and junior players was found [(M=29.9, S.D=32.62)] [(M=26.3, S.D=28.76)], $\mathrm{S}_{\mathrm{E}} \mathrm{D}=13.75$ and $\mathrm{t}-$ value $=0.26$ with $\mathrm{df} 18$ is found insignificant at 0.05 level of significance.

\section{CONCLUSION}

To conclude the present study demonstrated that male and senior players have high level of sports competition anxiety than female and junior netball players. But some time there is

(C) The International Journal of Indian Psychology, ISSN 2348-5396 (e) | ISSN: 2349-3429 (p) | 140 


\section{Sports Competition Anxiety among Netball Players}

insignificant difference found between mean scores of sports competition anxiety male and female, senior and junior netball players.

\section{Acknowledgments}

The author appreciates all those who participated in the study and helped to facilitate the research process.

\section{Conflict of Interests}

The author declared no conflict of interests.

\section{REFERENCES}

Ali, S., Adhikari, S., \& Nandy, S. (2012). The Relation between Anxiety and Sports Perfectionism of Kabaddi Players. International Journal of Scientific and Research Publications, 2(10):1-4.

Espejel, A., P., Walle, J., P., Rodriguez, J. T., Villanueva, M. M., \& Gurrola, O. C. (2011). Precompetitive Anxiety and Self-confidence in Pan American Gymnasts. Science of Gymnastics Journal, 5(1), 39-48.

Frued, S. (1949). Inhibition, Symptom and Anxiety. London: Hogarh Press.

Hannon, B., \& Fitzgerald, P. (2006). Anxiety and performance in elite non-professional athletes. Journal of International Medicine and Sports, 99(8):238-240.

Humara, M. (1999). The relationship between anxiety and performance: A cognitive behavioral perspective. The Online Journal of Sport Psychology, 1, 1-14

Inder, K. (2015). A comparative study of sports competition anxiety between district levels male volleyball and soccer players. International Journal of Physical Education, Sports and Health, 1(3): 53-55.

Jarvis, M. (2006). Sport Psychology a Student's Handbook. Routledge 27 Church Road, Hove, East Sussex, BN3 2FA.

Lizuka, P. (2005). Anxiety and Performance in Young Table Tennis Players. Sports Science Research, 26 (3):73-75.

Mitra, S., \& Gayen, A (2014). Sports competition anxiety level among the selected ballgame players: comparative study. Paripex Indian Journal of Research, 3 (11):53-54.

Nayek, B. \& Chatterjee, K. (2014). Comparative study on pre competition anxiety between national and state level women athletes. IOSR Journal of Sports and Physical Education (IOSR-JSPE), 1(2):33-36.

Quadri, S., J. (2013). A study of self concept and anxiety among boys and girls school players. Research Directions, 1(3).

Rastogia, N., K. \& Katiyar, V. (2014). A comparative study of sports competition anxiety test between college level chess and cricket players. International Journal of Physical Education, Fitness and Sports, 3(3):22-25.

Singh, J., K, \& Pal, J. (2015). Anxiety level of Kho-Kho players at national level: A scientific view. American Journal of Engineering Research (AJER), 4(8): 89-92. 


\section{Sports Competition Anxiety among Netball Players}

Singh, M, C., \& Singh, R., K., N. (2015). Comparative study on anxiety level between boys and girls football players. International Journal of Research Granthaalayah, 3(9):96-100.

Vujanovic, S., \& Tisma, M. (2011). Correlation between competitive anxiety and efficacy of athletes. Aktuelno u praksi, 23(10), 31-41.

Worchel, S., \& Goethals, G., R. (1989). Adjustment: Pathways to personal growth. Englewood Cliffs, NJ: Prentice-Hall.

How to cite this article: A Hassan, J Bhat, P Shelvam (2016), Sports Competition Anxiety among Netball Players, International Journal of Indian Psychology, Volume 4, Issue 1, No. 69, ISSN:2348-5396 (e), ISSN:2349-3429 (p), DIP:18.01.017/20160401, ISBN:978-1-365-45447-9 